\title{
CRONÓTOPOS DE UMA NAÇÃO DISTÓPICA: O NASCIMENTO DA "DEPENDÊNCIA" NO MÉXICO PORFIRIANO TARDIO"
}

Claudio Lomnitz

\section{Introdução}

Este artigo é um estudo sobre o início da formação da cultura do nacionalismo dependente, forma de consciência histórica que promove um realismo pragmático e imoral (geralmente acompanhado de demonstrações de melancólico remorso), e que justifica, com uma linguagem que fala de transição evolucionária, os benefícios privados obtidos em um tempo presente tido como deplorável. Entendo a dependência como uma condição específica que surgiu na América Latina quando as economias nacionais de seus países se reorientaram para os Estados Unidos, tendo este país passado a ser o detentor dos créditos nacionais - processo que começou a se delinear na década de 1870, mas que só se tornou realidade palpável por volta do fim dos anos 1890. No artigo, exploro a cultura da dependência por meio de seus "cronótopos", isto é, os modos com que a nação foi figurada no tempo e no espaço. Mais especificamente, descrevo duas figuras antagônicas que emergiram no período. Uma tomou forma em um novo campo de relações internacionais, enquanto a outra foi produto de uma emergente organização transnacional de base popular. Meu argumento é que estes dois quadros espaço-temporais conflitantes ("cronótopos") são uma característica definidora da dependência enquanto forma de consciência histórica.

\section{"Cronótopos" e independência}

O conceito de cronótopo foi primeiro formulado por Mikhail Bakhtin, para referir-se às matrizes espaço-temporais que são condição básica de todas as narrativas e atos linguísticos (Bakhtin 1981). Tais matrizes são elementoschave da ideologia e nelas uma simples imagem pode estar, iconicamente, no lugar de um conjunto de conexões postuladas entre tempo e lugar. Movimento 
no espaço pode ser figurado como movimento no tempo, e vice-versa razão por que um cronótopo é entendido como matriz.

As grandes transformações políticas envolvem mudanças de orientação. Elas exigem que a situação e o horizonte de expectativas dos atores coletivos se modifiquem. Por esta razão, a mudança política ou bem é guiada pela invenção de novos cronótopos, ou conduz a ela. Assim, por exemplo, líderes conservadores de movimentos de independência na América hispânica, como Agustín Iturbide, no México, usaram a imagem de uma árvore, ou a de uma família, para representar a conexão entre a Espanha e a Nova Espanha, e para justificar a independência: a Nova Espanha teria sido um ramo da árvore espanhola, mas tornara-se tão robusta que dela brotou um tronco próprio, e uma nova árvore tomou forma, de modo natural, em seu próprio solo. A nação mexicana, portanto, era um rebento da nação espanhola, e sua independência foi o desenvolvimento natural do ciclo de crescimento. Assim como os filhos se tornam independentes de seus pais, também o México deveria tornar-se independente da Espanha.

A implicação desse cronótopo tomado ao desenvolvimento espaçotemporal de formas de vida, como árvores e famílias, foi revolucionária e também conservadora, já que justificava a independência nacional ao mesmo tempo em que a enquadrava como reafirmação natural do modelo parental. O México, assim, podia aspirar a ter seu próprio imperium; e suas regiões, seus povos, seus lugares sagrados e praças urbanas podiam, cada um, ser usados como signos metonímicos do novo império mexicano.

Tal cronótopo conservador não era a única orientação disponível para as repúblicas da América hispânica no cenário mundial. Uma segunda formulação rejeitava a ideia de que as repúblicas eram como crianças crescidas em relação a seus pais amorosos, ou os orgulhosos rebentos de um grande e velho carvalho. A Espanha não era nenhum pai amoroso: as terras e os povos da América haviam sido saqueados por conquistadores implacáveis; foram deliberadamente mantidos em estado de abjeta ignorância por um clero ardiloso e retrógrado, e depois explorados sem clemência por mesquinhos mercadores "estrangeiros" (espanhóis), que nada mais queriam além de manter o povo da América em seu estado degradado. Nessa formulação, os povos americanos existiam como nações antes da espoliação espanhola. A independência era uma rejeição da exploração colonial, o ato de um povo que encontrara esperança na nova idade da razão. Em vez de defrontar-se com a Espanha como um jovem diante de seus pais, o povo era simultaneamente a prova do potencial esclarecido das novas repúblicas e a vítima degradada, deformada e espoliada da usurpação espanhola. Este segundo cronótopo da libertação nacional, que acabou por encontrar seus símbolos 
nas pirâmides e nas paisagens virgens, retratava a independência como o grandioso começo de um processo de emancipação que perduraria até que se extirpasse o último vestígio da presença colonial.

\section{Por que dependência?}

"Dependência" é um conceito que foi originalmente proposto pelos sociólogos latino-americanos Fernando Henrique Cardoso e Enzo Faletto como uma nova teoria do imperialismo, a qual sublinhava uma longa história de trocas desiguais entre centros manufatureiros e as economias extrativas que eles impunham às suas colônias. A ideia-chave da teoria da dependência era a de que o "subdesenvolvimento", mais que falta de desenvolvimento, era um tipo específico de desenvolvimento capitalista (Cardoso \& Faletto 1979). Como teoria econômica, a "dependência" foi refutada em diversos aspectos fundamentais.

Não pretendo reviver a teoria da dependência como tal. Na verdade, invoco o termo "dependência" porque ele nomeia convenientemente uma época histórica no amplo arco da história pós-colonial. O termo "pós-colonial" é demasiado largo para uma análise da história da América Latina em seus mais de 200 anos de existência independente. Da maneira com que emprego o conceito aqui, a dependência refere-se a uma época da história pós-colonial que vai aproximadamente dos anos 1890 até a recente desarticulação do "consenso de Washington", quando as nações independentes se reorientaram para um novo poder imperial (não-colonial), cujo capital gerava desenvolvimento rápido e intenso e novas modalidades de "subdesenvolvimento". O México foi talvez a primeira das nações a passar por essa transição.

\section{Novos cronótopos da dependência}

Os modos mexicanos de narrar a nação no interior do tempo histórico, durante o início do período pós-colonial, podem ser vistos, através da larga lente da história, como se descrevessem um arco que se inicia em um horizonte de expectativas utópicas nos primeiros dias no movimento nacionalista; passa pelo sentimento de desespero em torno das dissensões civis e dos vários "pecados da nação" - um sentimento negativo que tem seu auge nos anos que se seguem imediatamente à guerra com os Estados Unidos (1848); passa também pelo sentimento ainda tentativo de novas aspirações 
nacionais após o triunfo sobre os franceses em 1867; e finalmente chega a uma fórmula de desenvolvimento que envolvia um "realismo" progressista e geralmente em causa própria, segundo o qual o presente era um estado perpétuo de devir, uma espécie de prelúdio à verdadeira história nacional, à verdadeira soberania nacional.

Dessas transições, a mais recente é a que vai da percepção de novas possibilidades, em seguida à Intervenção Francesa (1867), para a legitimação de uma ditadura progressista sob Porfirio Díaz (c.1888), e que pode ser resumida, respectivamente, por dois cronótopos-guias: o do presidente Sebastián Lerdo de Tejada e o do presidente Porfirio Díaz. Lerdo, deposto em 1876 por um golpe liderado por Díaz, opunha-se a uma ligação ferroviária com os Estados Unidos e forjou seu famoso lema: Entre la debilidad y la fuerza, el desierto ["Entre a fraqueza e a força, o deserto"]. A utopia da soberania nacional e da autodeterminação, que se reabrira com a vitória sobre os franceses, era bastante frágil aos olhos de Lerdo. Para ele, o México era muito fraco para resistir a uma corrida de investidores, colonizadores, aventureiros, especuladores e dólares dos EUA. A interferência ianque deveria ser restringida ao mínimo, sem a construção de linhas diretas de transportes de massa.

A famosa contrafórmula de Díaz foi: "Pobre México, tão longe de Deus e tão perto dos Estados Unidos". Na época, esse cronótopo tinha nuances distintas das que tem hoje. A referência à distância de Deus claramente sintetizava uma crítica ao utopismo liberal anterior: o México estava longe de Deus porque os mexicanos estavam longe de ser cidadãos virtuosos. Em 1876 isto era bastante óbvio, pois em seguida à derrota dos franceses e do Partido Conservador, em 1867, os liberais vitoriosos não cessaram de lutar entre si. O novo consenso era que os mexicanos ainda não tinham as qualidades necessárias para atingir os ideais superiores da democracia liberal. Por essa razão, Díaz argumentava, o poder dos EUA era a indigesta realidade que o México deveria enfrentar. Em vez de insistir em uma inalcançável utopia republicana, que tinha o deserto mexicano como único fiador, o verdadeiro patriotismo demandava a manipulação pragmática das relações internacionais: abrir o México ao investimento de capitais americanos, mas com o uso da paz e do progresso para transformar a cidadania; equilibrar as concessões aos EUA com outras às potências europeias, para evitar a subordinação a uma nova relação colonial. Esta é a lógica da dependência e, com efeito, o porfiriato foi a época em que surgiu a cronotopia da dependência. ${ }^{1}$

A ditadura de Porfirio Díaz marcou uma transformação nas relações entre México e Estados Unidos. Os investimentos americanos em mineração, ferrovias e agricultura elevaram-se vertiginosamente (Hart 1987; Nugent 
1998; Schell 2001). Junto com esses investimentos, vieram amplas campanhas publicitárias nos EUA a favor do México. Elas geralmente envolviam remodelação da história deste país e das relações com aquele. Da parte dos EUA, essas campanhas foram orquestradas, no início, pelo diplomata mexicano Matías Romero que, junto com grandes investidores de Nova York, Philadelphia e outras cidades, ofereceu incontáveis banquetes que serviram como ocasiões propícias à publicização da nova imagem mexicana e à realização de negócios.

Nessas ocasiões, Romero e os grandes investidores da época trabalharam conjuntamente para refigurar a história do México. Assim, por exemplo, em um banquete para investidores realizado em 1891, em Nova York, intitulado "Uma noite mexicana", Walter Logan proferiu um longo discurso em que apresentava sob luz favorável o país e sua história: "Será que [Díaz] de fato será como o nosso Washington, imensamente grandioso em tempo de guerra, mas ainda maior em tempo de paz? Será ele, como Washington, capaz de construir, assim como foi capaz de destruir? O destino do México depende da solução dessa questão. [...] Desse homem, mais do que de qualquer outro vivente, pode se dizer que é o Criador de uma Nação" (Romero 1892:168-70).

Por que razão Díaz - um homem que assumira o cargo quando já se haviam completado 55 anos de independência e nove anos da derrota dos franceses - foi designado como pai da nação? Porque, em 1891, seu governo deu condições para uma profunda reorientação da economia e da sociedade mexicanas. Com Díaz, a nação passou da condição de democracia altamente instável, estagnada economicamente e isolada no plano internacional para uma situação de paz, crédito internacional e crescimento econômico sob uma ditadura progressista.

Matías Romero escreveu, difundiu e refinou novas versões da história nacional, defendendo o México de seus detratores, fornecendo a respeito do país, para o público americano, informações estatísticas, históricas, econômicas, jurídicas e políticas, ajudando a mostrar, por exemplo, que os baixos salários eram contrabalançados por baixa produtividade e altos custos de transporte, não representando, portanto, ameaça aos trabalhadores dos EUA; que a servilidade dos trabalhadores rurais no sul do México não era o mesmo que escravidão etc. ${ }^{2}$

O próprio México tornou-se uma arena de demonstração para capitalistas, diplomatas, intelectuais e jornalistas americanos, com demonstrações encenadas de ordem pública, hospitalidade, potencial financeiro e contentamento humano. Isto foi acompanhado do investimento na imagem do país no exterior, através da participação em feiras mundiais, congressos científicos 
internacionais e publicações. Em suma, ao fim do período do porfiriato, encontrava-se bem estabelecido um elaborado sistema de comunicação com e através do público americano e seu correspondente econômico, Wall Street. ${ }^{3}$

No entanto, a imagem internacional do México, tão cuidadosamente manejada, enfrentou um desafio tenaz, embora aparentemente inofensivo de início: a fronteira com os EUA, espaço de um tráfico cada vez mais intenso e instável. Iniciado ao fim da década de 1880 e impelido pelo fim das guerras com os Apache e pela construção da ferrovia de ligação com os EUA, em El Paso/Ciudad Juárez, desenvolveu-se um conjunto muito menos domesticado e menos facilmente controlado de representações. Eram os primeiros anos da emigração intensificada de trabalhadores para os EUA. ${ }^{4}$ Nos campos do Texas e nas minas do Arizona, os mexicanos tornaram-se uma "raça", mais que uma nacionalidade. Este foi, por si, um processo perturbador para a imagem nacional, ainda que diretamente dissesse respeito apenas a uma minoria de mexicanos. Além disso, as cidades de fronteira passaram a ser culturalmente relevantes para o México: opositores políticos de Díaz podiam publicar suas opiniões, mantendo conexões em ambos os lados. ${ }^{5}$ Ao fim dos anos 1890, na fronteira, a publicação de jornais em espanhol e em inglês era um próspero negócio e constituía uma dinâmica cena política, com as pessoas deslocando-se entre México e EUA e valendo-se das condições em um dos países para intervir nas condições do outro.

Essa nova modalidade de transnacionalismo teve efeitos produtivos, mas também desestabilizadores. Cada nação tinha seus próprios "regimes de valor" - como se vê não só nas diferenças entre as moedas nacionais (referidas ao ouro e à prata como padrões monetários), mas também no contraste entre os valores comparativos do trabalho, dos bens de consumo, dos instrumentos mecânicos etc. Como resultado dessas diferenças, o trânsito através da fronteira podia ter efeitos quase mágicos: gente do povo, pessoas simples do lado americano, por exemplo, transformavam-se em membros de uma casta quase aristocrática, sendo recebidos por pessoas da elite local e servidos por empregados.

O movimento de fronteira também teve o efeito de fazer dos imigrantes mexicanos membros de uma "raça" segregada e discriminada; nessa condição, eles puderam tornar-se verdadeiros defensores da causa da nacionalidade. Assim, por exemplo, Catarino Garza, um jornalista que havia emigrado para o Texas meridional em 1877, defendeu nos seguintes termos a raça mexicana contra a difamação na imprensa texana:

Nós, mexicanos, nos consideramos mais puros de sangue do que os americanos, dado que em nosso país há apenas mistura de espanhóis e índios, e que 
eles [os americanos] são geralmente descendentes de aventureiros irlandeses, mendigos poloneses, suíços, prussianos, russos e, mais que tudo, africanos repugnantes (Young 2004:50).

Os mexicanos - assim argumentava Garza - tinham sangue mais puro, tradições mais nobres e melhores costumes do que os americanos, no entanto, eram tratados como massa ignara e usados como recurso para manobras eleitorais, transportados em carroças através da fronteira do Texas em troca de álcool para votarem em eleições fraudulentas. "O México é malvisto por causa dos imigrantes que vieram para este país", afirmava (Young 2004:46). A autoimagem de Garza como defensor da raça foi regularmente alimentada em sua prática jornalística, nos desafios a duelos que lançava aos anglos que ofendiam mexicanos e nos galanteios dirigidos às mulheres americanas que, segundo ele, "amam por conveniência, [e] são tão fáceis de amar quanto de esquecer e abandonar" (Young 2004:31-33).

As pressões crescentes para "defender a raça" só fizeram aumentar a tentação de mudar as coisas no país de origem, e acabaram por levar Garza a extremos de desespero (ou de megalomania), como insultar a honra do general Bernardo Reyes, do exército mexicano, e liderar do sul do Texas uma rebelião para derrubar o presidente Díaz. Era o trânsito na fronteira que dava ousadia a esses imigrantes mexicanos, esses libres fronterizos [fronteiriços livres]; eles haviam desmistificado os "anglos" falsamente superiores e fizeram de si mesmos os representantes das mais viris qualidades de sua raça.

Outro exemplo de dissonância cultural e instabilidade produtiva resultante do novo transnacionalismo é o caso de Teresa Urrea, a assim chamada Santa de Cabora, curandeira virgem tornada líder religiosa messiânica, elevada a ícone de revolta em uma série de rebeliões em Sonora, entre os Mayo e os Yaqui, e em Chihuahua, a mais famosa delas em Tomochic, em 1893. A Santa de Cabora tem sido comparada a outros líderes milenaristas da América Latina durante o mesmo período, e especialmente a Antônio Conselheiro, de Canudos, nordeste do Brasil, martirizado pelo exército brasileiro. No entanto, a situação de fronteira leva a história de Teresa Urrea para uma direção inteiramente distinta.

Em vista da assustadora popularidade de Teresa e de sua proximidade da fronteira, o governo Díaz preferiu exilá-la a torná-la mártir. Assim, Teresa foi para o lado americano de Nogales, onde foi recebida pela comunidade local de negócios como "Joana D'Arc mexicana". Ao contrário do que havia sido sua experiência no México, onde fora perseguida pelo poder legal, Teresa teve todas as facilidades para se estabelecer em Nogales, em função dos negócios que se fariam ali graças às multidões que ela atraía e curava. 
De Nogales, a Santa de Cabora mudou-se para Tucson, para Douglas e, afinal, para a Califórnia. Desses lugares, ela ocasionalmente voltava sua atenção para os assuntos mexicanos, e censurava a política de Díaz contra os Yaqui, por exemplo. Mas sua vida transformou-se completamente. Em Cabora, Urrea recebia peregrinos — índios Mayo e Yaqui - e mexicanos do deserto remoto; sua imagem estava estampada em escapulários e era erguida nas bandeiras das rebeliões das aldeias. Nos EUA, sua vida foi lucrativa. Ela tinha um agente, que lhe pagou US\$10.000 para que realizasse um tour nacional de exibição de suas "curas milagrosas" (Vanderwood 1998:304). A travessia de fronteira transformara uma religiosa milenarista carismática em uma atração de circo.

O caso de Garza e o de Urrea são, de diferentes modos, exemplares quanto às transformações culturais que se deram na fronteira México-EUA por volta dos anos 1890. Enquanto o governo mexicano e os interesses americanos por negócios trabalhavam para estabilizar a imagem do México como uma espécie peculiar de "república irmã", as novas terras de fronteira geravam novos movimentos sociais e formas culturais.

\section{Duas travessias de fronteira}

O México havia encontrado uma nova fórmula de estar no mundo, objeto de corretagem internacional nos níveis mais altos de governo, ciência e negócios. Estimulada pela importação maciça de capital e pela expansão rápida dos mercados de exportação das mercadorias mexicanas, a nova estratégia de desenvolvimento também gerou entre as camadas populares uma versão menos controlada de internacionalismo, que vimos chamando de transnacionalismo, e que envolveu o deslocamento de pessoas entre dois países. Estas duas modalidades de internacionalismo - relações internacionais corretadas pelo governo, transnacionalismo em versão popular produziram para o México cronótopos contrastantes.

Para entender a razão por que foi assim, é útil observar as experiências muito diferentes de travessia de fronteira que corresponderam a tais modalidades contrastantes, e a seguir examinar que tipo de produtos de conhecimento surgiu a partir delas. Começarei apresentando duas imagens de travessia de fronteira como casos típico-ideais (e não como estatisticamente representativos).

Em 1891, o antropólogo norueguês Carl Lumholtz cruzou a fronteira EUA-México, próximo a Bisbee (Arizona), a caminho da Sierra Madre, na qualidade de chefe de uma expedição geográfica. Antes de passar o limite 
entre os estados de Arizona e Sonora, Lumholtz esteve em Washington D.C., onde "o finado Mr. James G. Blaine, então Secretário de Estado, fez tudo que estava a seu alcance para preparar meu caminho até o México, chegando mesmo a revelar um forte interesse pessoal pelos meus planos" (Lumholtz 1987 [1902]:viii).

Com o apoio político do secretário de Estado norte-americano e o apoio financeiro do American Museum of Natural History e de alguns dos mais destacados capitães de indústria e de finanças de Nova York - inclusive Andrew Carnegie, Pierpont Morgan, Augustus Schermerhorn e George Vanderbilt, entre outros — Lumholtz viajou até a Cidade do México, onde foi

recebido com a mais extrema cortesia pelo presidente, o general Porfirio Díaz, que me concedeu audiência de uma hora no Palácio Nacional, e também por vários membros de seu gabinete, que me deram demonstração verdadeiramente gratificante de apreciarem a importância e o valor científico da minha proposta (Lumholtz 1987 [1902]:viii-ix).

Com respaldo das cartas de apresentação assinadas pelo presidente, por vários ministros e governadores de estados, Lumholtz voltou aos EUA, terminou de preparar sua expedição e então partiu. Seus objetivos combinavam o registro dos modos de vida de um povo primitivo e o desbravamento de uma região que estivera fora do alcance dos investidores americanos e mexicanos devido à guerra com os Apache, que havia se encerrado apenas alguns anos antes. Assim, Lumholtz afirmou que:

Os povos primitivos estão escasseando no planeta. Nos continentes americanos ainda há alguns que permanecem em seu estado original. Se forem estudados antes que também eles percam sua individualidade ou sejam pisados e esmagados pela civilização, lançar-se-á bastante luz não apenas sobre a população original desta terra, mas sobre os primeiros capítulos da história da humanidade (Lumholtz 1987 [1902]:xvi).

Lumholtz foi especialmente atraído pelos Tarahumara, pois havia relatos de que eles seriam "habitantes das cavernas", como os extintos e misteriosos Anasazi, do Novo México. Mas a pesquisa de Lumholtz foi concebida para ser tanto monumento quanto epitáfio desses povos primitivos, uma vez que a expedição, com sua equipe de cientistas — incluindo um botânico, um geólogo e um cartógrafo - tinha a intenção de abrir a Sierra Madre à exploração econômica. Assim: 


\section{Figura 1}

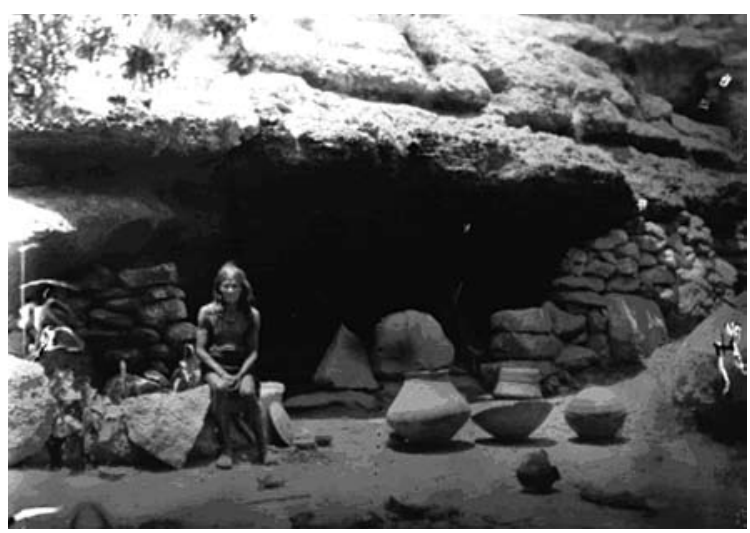

Tarahumara. Fotografia de Carl Lumholtz, anos 1890 , cortesia do American Museum of Natural History.

As vastas, magníficas florestas virgens e a riqueza mineral das montanhas não permanecerão por muito tempo como propriedade de meus obscuros amigos; mas espero prestar-lhes um serviço erigindo a eles esse modesto monumento, e que o homem civilizado venha a aprimorar-se ao conhecê-los (Lumholtz 1987 [1902]:xvi-xvii).

Claramente, o projeto de Lumholtz era uma produção internacional, característica das novas condições de dependência. Apoiava-se simultaneamente nos interesses dos investidores nova-iorquinos e nas autoridades americanas e mexicanas. É verdade que essas sensibilidades "orientalistas" levaram a formas de exotização e a apropriações não reconhecidas, geralmente associadas ao colonialismo. No entanto, tais representações e práticas também foram adotadas pelas autoridades mexicanas e pelo público instruído do país. Em outras palavras, o trabalho de Lumholtz é uma espécie de ciência "orientalista", sintonizada com uma forma pós-colonial de dependência, mais do que com o colonialismo enquanto tal.

Era muito recente, então, a abertura da Sierra Tarahumara aos empreendimentos mexicanos ou estrangeiros; ela era um dos refúgios favoritos dos guerreiros apache antes de sua derrota final, em meados dos anos 1880. Os traços ferozes dos Apache foram simbolicamente apropriados pelos colonos mexicanos que haviam "pacificado" essa fronteira. "Aos olhos dos colonizadores", escreve Ana Alonso, "os Apache se tornaram epítome de masculinidade indomável, concebida como base 'natural' do poder e da autoridade" (Alonso 1997:71). Mas nessa apropriação dos extintos Apache, Lumholtz tomou parte de maneira própria e bem diferente.

Quando deu início à sua expedição, Lumholtz tinha com ele 30 homens, incluindo americanos rústicos e racistas, mexicanos, índios. Após alguns 


\section{Figura 2}

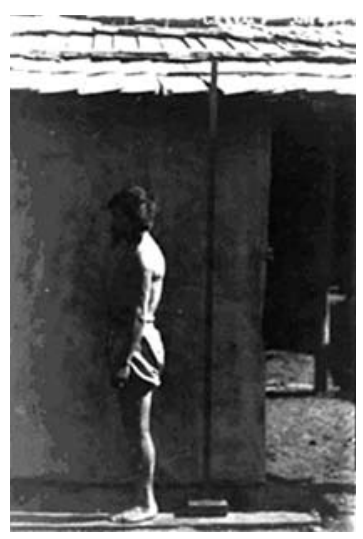

Fotografia de Carl Lumholtz. Espécime antropométrico tarahumara. Década de 1890. Cortesia do American Museum of Natural History

meses, ele decidiu livrar-se de toda essa entourage e ficar apenas com seu cão, Apache, ao qual dedicou algumas linhas comoventes:

Apache provinha de São Francisco. Ele me foi presenteado por um jovem amigo, e ainda estava na infância quando, seis verões atrás, se aventurou sozinho até Bisbee, numa caixa de remessa rápida, para juntar-se à minha expedição. Do lado materno, ele vinha de uma das melhores famílias caninas dos Estados Unidos, e em todas as minhas viagens pelo México foi meu aide-de-camp eficiente e constante. [...] Enterramo-lo, como um índio de bravura, com seus pertences, sua coleira e a corrente, as tigelas e cobertores (Lumholtz 1987 [1902]:78-81).

Em vez de representar sua própria masculinidade, os Apache, aquele mesmo povo que até 1890 havia mantido a Sierra Madre fora do alcance de viajantes como Lumholtz, estavam agora contidos no espírito do animal de raça pura, o companheiro e servidor mais fiel de Lumholtz. Os Apache e os Tarahumara representavam o passado no presente: aqueles, como espírito indomável; estes, como confirmação viva da verdade de um passado que tomava forma em museus e livros didáticos, graças aos esforços dos congêneres de Lumholtz e seu fiel Apache.

Passemos agora a uma travessia diferente, que se deu no fim do período que estamos examinando, em 1914, na fronteira Texas-Chihuahua.

Boêmio do Greenwich Village, jornalista, diplomado em Harvard, socialista, John Reed chegou à poeirenta cidade de Presidio, Texas, para cruzar a fronteira, alcançar Ojinaga, e cobrir a revolução que ocorria no sul do país. O jornal socialista para o qual trabalhava não lhe forneceu nenhuma carta que o apresentasse ao presidente Huerta, que de qualquer modo estava 
sendo deposto do poder naquele mesmo momento. A viagem até lá também não envolvera longas conversas com investidores nova-iorquinos, nem com o Departamento de Estado. Em vez disso, Reed fez seus contatos em um bar de Presidio, uma cena que ele descreveu muito bem, numa memorável anotação breve:

Em todas as horas do dia e da noite, ajuntamentos de soldados federais [mexicanos] desarmados, vindos do outro lado do rio, enxameavam a loja e o salão de bilhar. Entre eles circulavam pessoas sombrias, agourentas, de ar importante, agentes secretos dos Rebeldes e dos Federais. Ao redor, na mata, acampavam centenas de refugiados miseráveis, e era impossível passar por uma esquina, à noite, sem esbarrar em alguma intriga ou contraintriga. Havia policiais texanos, soldados da cavalaria dos Estados Unidos e agentes de empresas americanas tentando passar instruções a seus empregados no interior do país (Reed 1969 [1914]:32).

Reed procurou ter acesso ao general Mercado, que estava sendo acossado pelas forças comandadas por Pancho Villa.

Eu queria entrevistar o general Mercado; mas um dos jornais publicara alguma coisa que desagradara o general Salazar, e ele proibiu repórteres na cidade. Mandei um pedido cortês ao general Mercado, mas a mensagem foi interceptada pelo general Orozco, que enviou a seguinte resposta: “Estimado e honrado senhor: se colocar os pés em Ojinaga, colocarei o senhor de lado junto a um muro e terei muito prazer em atirar com minhas próprias mãos e abrir sulcos em suas costas" (Reed 1969 [1914]:29-30).

Não foi bem esse o tipo de tratamento vip que Lumholtz recebeu das autoridades mexicanas. No entanto, Reed cruzou a vau o rio Grande, entrevistou quem ele queria entrevistar, juntou-se ao exército rebelde, cavalgou ao lado de Pancho Villa e escreveu um dos mais arrebatadores retratos do processo revolucionário.

Tanto Lumholtz quanto Reed escreveram livros importantes, mas o trabalho de Lumholtz rapidamente teve sua versão em espanhol e deixou profunda marca na etnologia mexicana, enquanto a obra de Reed passou praticamente despercebida até a década de 1960, apesar da grande fama que seu autor viria a angariar por conta da cobertura que realizou da Revolução Russa. Esta diferença está ligada aos fatores sociais que fizeram com que suas respectivas travessias diferissem tanto.

Podemos agora examinar de perto os cronótopos contrastantes gerados, respectivamente, pelas relações internacionais e transnacionais. Com este 
propósito, abordarei duas obras bem conhecidas: a entrevista Creelman-Díaz (1908), para o novo internacionalismo, e para o novo transnacionalismo, Barbarous Mexico [México bárbaro], de John Kenneth Turner (1910).

\section{Investimentos internacionais em um cronótopo de dependência: a Entrevista Creelman}

Em março de 1908, a Revista Pearson, de Nova York, publicou uma entrevista fartamente ilustrada com o presidente Porfirio Díaz. Nela, o ditador, envelhecido, anunciava que o México finalmente estava pronto para a democracia; afirmava que ele, Díaz, acolheria e mesmo apoiaria a formação de um partido de oposição, e que estava ansioso por se aposentar ao fim do mandato.

Embora Díaz tivesse por hábito, no início dos períodos eleitorais, negar qualquer interesse em estender a permanência na presidência, ele nunca antes declarara apoio à formação de um partido de oposição, nem apresentara tão claramente sua própria estada na presidência como uma ponte, já terminada, para a vida democrática. Uma versão resumida da entrevista com Creelman foi imediatamente traduzida para o espanhol e reproduzida em todo o país. Após essa entrevista, a política mexicana se abriu a uma ferrenha disputa eleitoral: estava encerrado o firme domínio que sobre ela Díaz exercera. Assim, a entrevista passou a ser referida pelos historiadores como a conclusão simbólica da ditadura.De modo geral, a entrevista a Creelman foi estudada do ponto de vista de seus efeitos na vida política mexicana, com especial atenção às múltiplas e constantes alusões feitas a ela como cobertura para a nova oposição a Díaz. No entanto, é surpreendente que para além da análise dos efeitos da declaração de tolerância e apoio à oposição, o conteúdo mesmo da entrevista tenha recebido pouquíssima consideração. ${ }^{6}$

Quais as implicações de fazer tais pronunciamentos-chave a um meio de comunicação americano, e não mexicano? Quais os dispositivos de enquadramento histórico e cultural que Creelman empregou para contextualizar as formidáveis declarações de Díaz? Uma análise da publicação nos permite entender mais fundo a opinião pública mexicana como um artefato produzido internacionalmente.

Uma das características marcantes e pouco exploradas da entrevista é o racismo discreto e, especialmente, o modo com que ele é usado para justificar a ditadura. Creelman abre a matéria com uma imagem grandiosa e melancólica que antecipa toda a justificação e a glorificação que dará a Díaz: 
Figura 3

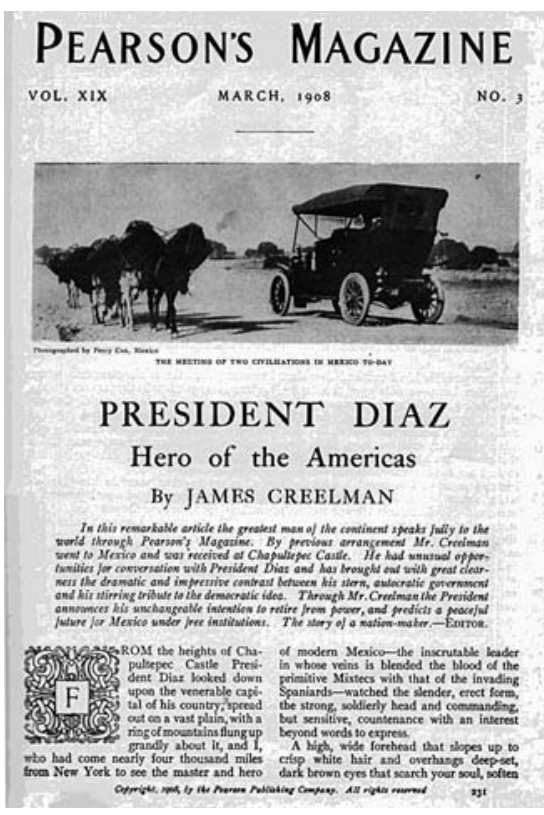

Primeira página da entrevista Creelman-Díaz

Das alturas do Castelo Chapultepec, o presidente Díaz olhou por sobre a venerável capital de seu país, espalhada pela vasta planura, com um anel de montanhas que se erguem majestosamente à sua volta, e eu, que saíra de Nova York e viajara mais de 6 mil quilômetros para ver o senhor e herói do México moderno - o líder insondável, em cujas veias o sangue dos mixtecas primitivos se mistura ao dos invasores espanhóis - fitei sua figura esguia e ereta, a forte e marcial cabeça, o semblante impositivo porém sensível, com um interesse impossível de expressar em palavras (Creelman 1908:231-232).

A partir deste notável cronótopo - um novo encontro entre México e Estados Unidos no Castelo Chapultepec; um encontro que já não é o de duas nações em guerra - Creelman passa a prestar homenagem ao grande líder que, sozinho, resgatou seu país das garras dos invasores europeus e da eterna atração para a indolência e a revolução. O herói, portanto, exige um retrato:

A testa alta e larga sobe até os cabelos, brancos e crespos, que caem sobre os olhos fundos, castanho-escuros; eles perscrutam a alma da pessoa, suavizam-se em delicadeza inexprimível e então dardejam rápidos olhares de esguelha olhos terríveis, ameaçadores, amorosos, confiantes, bem-humorados. Nariz reto, poderoso, largo e um pouco carnudo, cujas narinas recurvas se erguem e se di- 


\section{Figura 4}

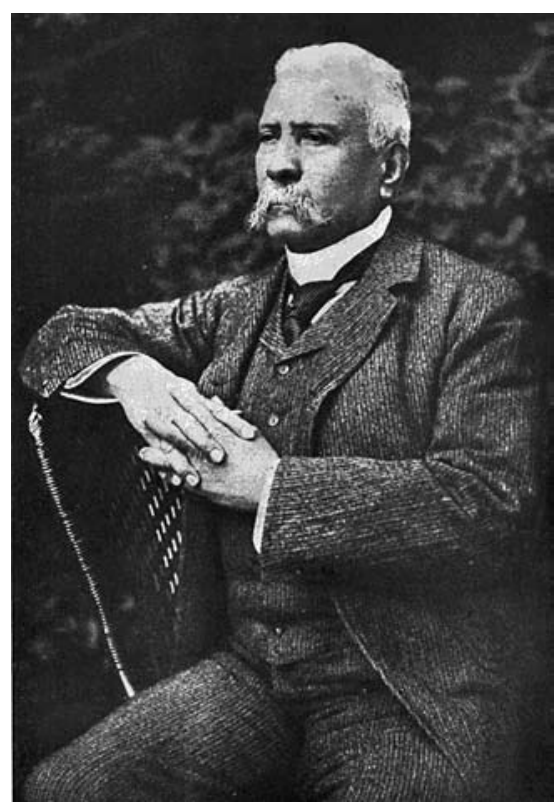

Retrato de Díaz na

abertura da entrevista

latam com cada emoção; maxilares imensos, viris, que se estendem das orelhas grandes, finas e achatadas junto à cabeça, até o queixo imponente, quadrado, de lutador; boca larga, firme, encoberta por um bigode branco; pescoço curto e grosso, musculoso; ombros largos, peito proeminente; porte curiosamente tenso e rígido, que confere grande distinção a uma personalidade sugestiva de grande poder e grande dignidade - este é Porfirio Diaz em seu septuagésimo oitavo ano de vida, tal como o vi, algumas semanas atrás [...] (Creelman 1908:231-232).

Esta detalhada descrição está escrita no idioma cifrado da fisiognomonia, pseudociência que foi popular em França, Alemanha, Inglaterra e Estados Unidos e, de fato, também na América Latina, largamente empregada por escritores e jornalistas para sintonizar os leitores com as características raciais e as qualidades preponderantes de uma personalidade.

Mostrei a uma historiadora da fisiognomonia, Sharrona Pearl, a descrição de Porfirio Diaz feita por Creelman, e ela não hesitou em sua interpretação: a dimensão-chave é o sangue misto, e ele é figurado, basicamente, como positivo. A maioria dos traços tomados por Creelman como marcas de poder e força poderiam também ser lidos por seu público como primitivos tanto como melhoramento positivo dos espanhóis em degeneração quanto, potencialmente, como marca de limitações intelectuais. A testa indica 
inteligência, assim como os olhos; o fato de estes serem fundos poderia ser sinal de falta de rigidez, talvez certa irresponsabilidade, assim como alguma limitação da capacidade de ler. O nariz é "grego", o que é excelente, mas ele tem traços achatados, e isto atenua um tanto a virtude heróica de Díaz assim como é o caso do olhar evasivo e da dilatação das narinas, elementos que também aparecem em outras partes da entrevista. Em poucas palavras: Díaz é valoroso, refinado, ousado, inteligente, mas um tanto bruto. ${ }^{7}$

Todas estas qualidades, que levam Creelman a um verdadeiro culto ao herói, também marcam Díaz como líder de seu povo, isto é, o líder natural de um povo inferior. Este conceito foi desenvolvido na fisiognomonia em meados do século XIX, nos EUA, e não raro usado por jornalistas, como Creelman, em publicações sensacionalistas, assim como pelos romancistas da época, dos dois lados da fronteira. O emprego da fisiognomonia por parte de correspondentes internacionais da imprensa marrom merece alguma atenção, porque fornece uma pista para o modo com que certo tipo de "ética da temporalidade" era manejada e desenvolvida nos EUA pela máquina publicitária pró-Díaz.

A fisiognomonia foi popularizada principalmente para auxiliar os habitantes urbanos a navegarem nas relações interpessoais no novo meio ambiente das cidades industriais do século XIX (Gray 2004; Pearl 2005). No entanto, ela também serviu de modo mais amplo para figurar e justificar as relações raciais. Assim, por exemplo, Samuel Wells, médico americano cujo manual de frenologia e fisiognomonia ainda estava em circulação na época de Creelman, afirmava que

os órgãos especiais em que o cérebro caucasiano se mostra superior, e que mais o distinguem daqueles das raças menos desenvolvidas, são a Jovialidade, a Idealidade e a Conscienciosidade, sendo os órgãos destas faculdades quase invariavelmente reduzidos entre as tribos selvagens e bárbaras (Wells 1894 [1869]:vii).

Mais especificamente, a colonização europeia da América era, de certo modo, um resultado natural do maior desenvolvimento cerebral das inclinações do "grupo egoísta".

A escravidão, a dominação colonial e a exploração de classe do homem negro também encontravam, por sua vez, apoio análogo nessa "ciência" popular.

Assim, as esmeradas descrições da estrutura craniana e do porte geral de Díaz - e a entrevista está cheia delas - são simultaneamente um retrato do herói e da sua raça. Um exemplo assustador do modo como isso se dá 


\section{Figura 5}

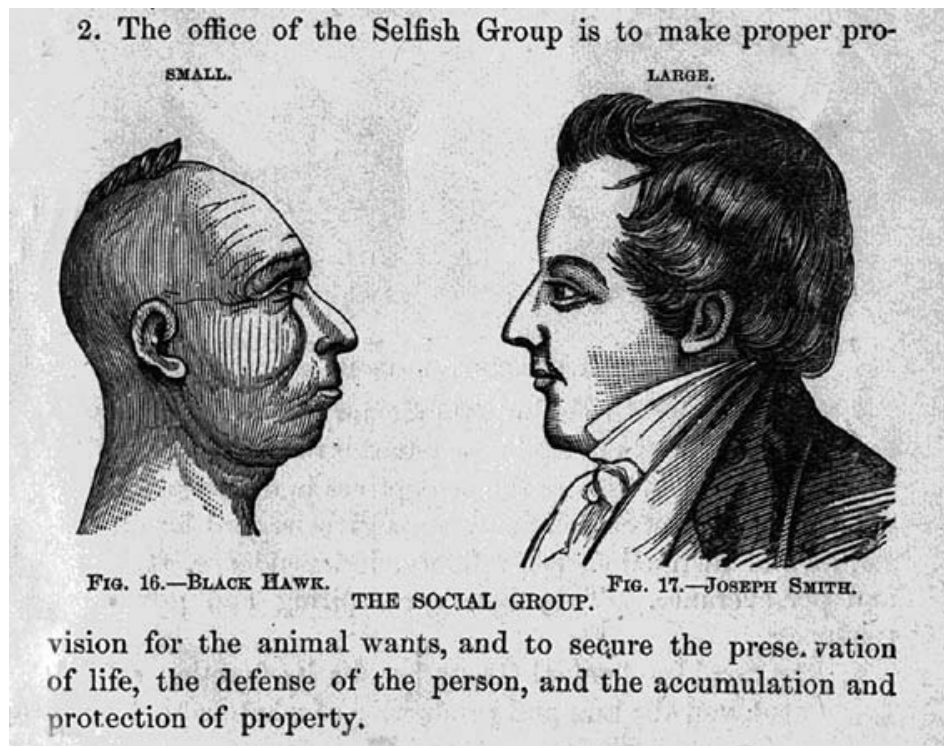

Black Hawk versus Joseph Smith, ilustração do livro de Samuel Wells (:31). Os órgãos do cérebro estão agrupados em regiões distintas: a região espiritual, a do intelecto, a das inclinações. As "inclinações" são, por sua vez, divididas em dois grupos: o social e o egoísta. A figura ajuda a entender por que os índios americanos com tanta facilidade abriram mão de sua propriedade para os gananciosos britânicos

\section{Figura 6}

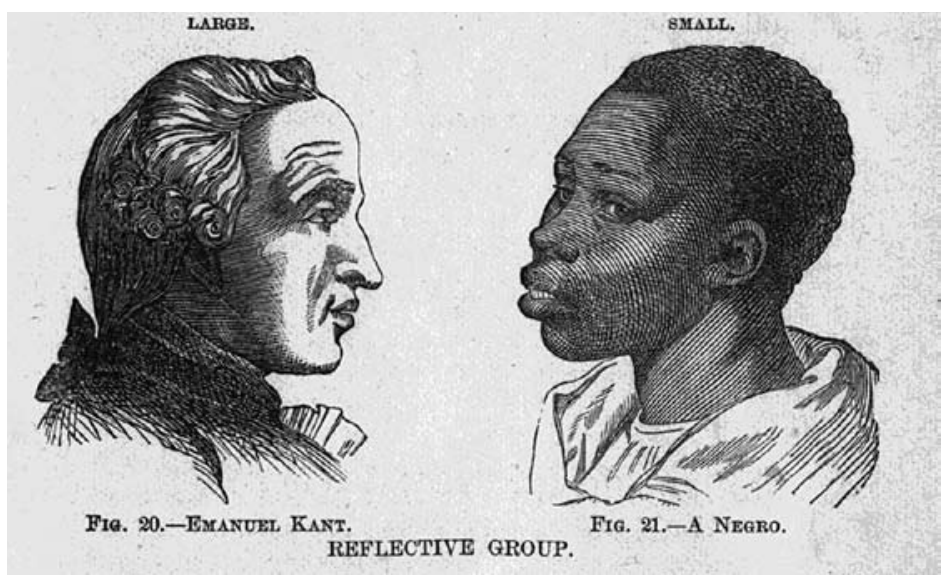

Do livro de Samuel Wells (:33). Aqui se mostra que Immanuel Kant - ao que parece, um espécime típico da raça caucasiana - tem estrutura craniana que favorece muito mais a habilidade analítica, a inventividade e a originalidade do que um não menos famoso representante de outra raça: "um negro". 
pode ser encontrado em outro manual popular de fisiognomonia, também americano. Comparative Physiognomy ([Fisiognomonia Comparativa] 1852), de James Redfield, que ainda tinha influência na escrita popular, afirma que o tipo superior de líder assemelha-se aos leões - Redfield menciona como exemplos John Jacob Astor e DeWitt Clinton, governador do estado de Nova York e construtor do Canal Erie. Como povo, os alemães se assemelham a leões. Há, porém, outros tipos de líderes mais parecidos com gatos. Entre eles, de maneira interessante, está o conquistador espanhol Hernán Cortés:

Na página seguinte há um retrato de Cortez, e vê-se que se parece com um puma. Um temível gato está para apanhar os camundongos, cujas figuras estão esculpidas nos monumentos da América Central, e que são representadas em Crianças Astecas! (Redfield 1852:31-32).

De fato, neste livro, e à força de numerosas exibições internacionais de Máximo e Bartola - duas crianças deformadas que, segundo se alegara, seriam descendentes puros dos astecas — o dr. Redfield identifica a fisionomia asteca com a dos camundongos. ${ }^{8}$ Além disso, ele afirma haver uma afinidade natural entre vítimas e executores. Assim,

pessoas semelhantes a corujas são atraídas em direção aos astecas, e neles encontram a gratificação de seus gostos e um largo campo para o exercício de suas afeições e predileções. O mesmo se aplica àqueles que se assemelham aos gatos. No gato as qualidades do camundongo estão assimiladas, e ele só pode amar aquilo que o gratifica, e que corresponde à sua natureza brincalhona, o refinamento, a esperteza e tantos outros elementos da sua natureza (Redfield 1852:67).

Se levarmos essa lógica racial adiante, até o texto de Creelman, descobriremos um duplo movimento no retrato adulador de Díaz ali traçado. Por um lado, Díaz era "a mais preeminente figura do continente americano", "um homem impressionante", e "não há figura mais romântica ou heróica no mundo". Por outro, havia a sugestão de que a grandeza de Díaz era conjuntural, um efêmero artefato histórico, e não o anunciador de, digamos, uma nova raça dominante. A grandiosidade de Díaz era o resultado do encontro de um líder obstinado e um povo degradado. A bem-sucedida elevação desse povo era um merecido tributo ao líder em seus últimos anos de vida.

Esta interpretação está bem evidente na entrevista a Creelman, mas é ainda mais óbvia na biografia de Díaz, que o mesmo autor escreveu dois anos depois, em 1910, com espírito bem mais defensivo, em face das duras críticas agora dirigidas, tanto no México quanto nos EUA, ao governo dita- 


\section{Figura 7}

\section{CoMrakatrve viryetonomy.}

sot, has but ono pair of eutting tooth in ench jnw. To the exorciso of gnawing wo slould imagino that nothing conlal bo bottor suited than tho crackor which
constitutes thoir principal food. Thoy
nro vonderfully inisehiovous but not
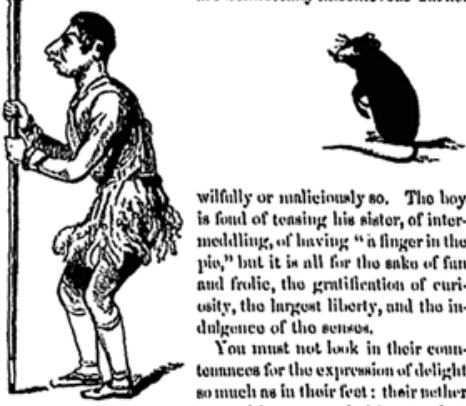

wilfully or unlieinuxly so. Tho hoy is foul of tensing lis sister, of intermeldling, of having " i finger in tho pie," lout it in all for tho sake of fur and frolic, tho grntifiention of curiusity, the langest literty, atul tho indulgence of tho senxus,

Fou must not lonk in their conath. tounuees for tho expreseion of thlight so mueh ne in their feet : their neslur extromitien nore curimition erpual to
Do livro de James Redfield (:66): "Os astecas são como camundongos". O retrato de Máximo, à esquerda, é reprodução fiel do desenho incluído no American Journal of Medical Sciences, v. 20: 290, 1851 (reproduzido em Juan Comas, apêndice não-numerado).

\section{Figura 8}
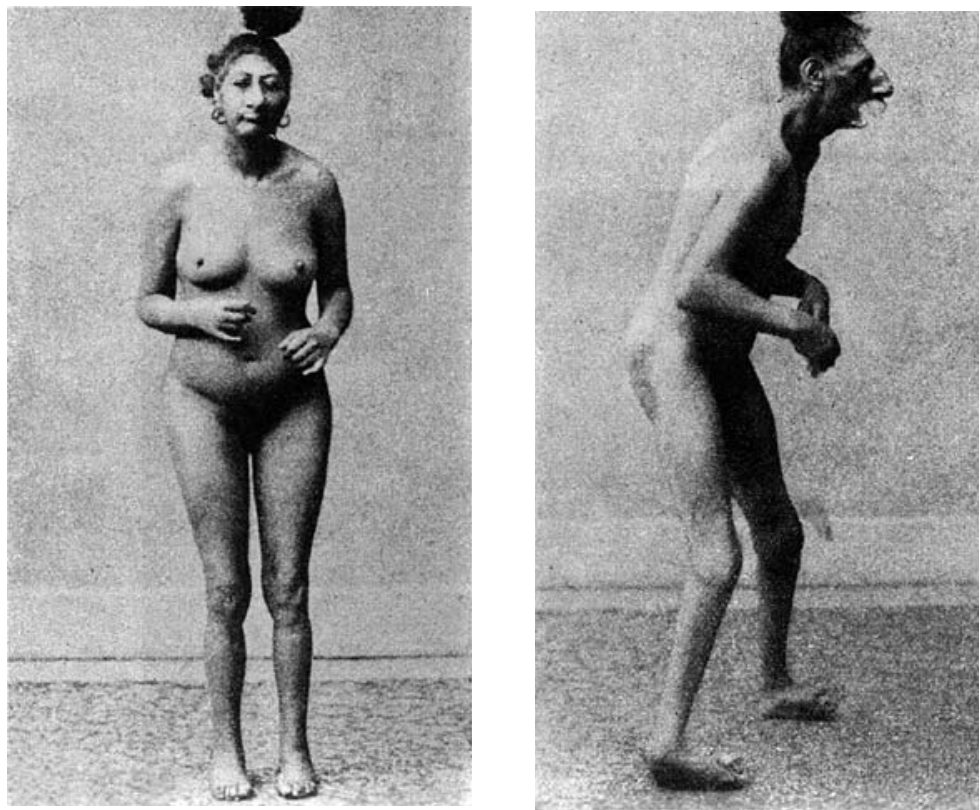

Bartola e Máximo, as assim chamadas "crianças astecas", de quem se afirmava que haviam sido capturadas de uma cidade intocada do povo asteca, chamada Izamal uma história fraudulenta, criada a partir de um relato do viajante americano John L. Stephens, cujas viagens em lucatã foram um retumbante sucesso. Bartola e Máximo foram, na verdade, comprados e tirados de seus pais na Costa Rica, onde haviam nascido, e levados em turnês pelos Estados Unidos e pela Europa, a partir de 1851, até morrerem. A fotografia é de 1901, por ocasião do exame a que o antropólogo alemão Rudolph Virchow os submeteu. Publicada em Zeitschrift für Ethnologie, 1901, v. 33:349-350. 
torial. Creelman mostrou-se aí mais direto a respeito do problema racial no México, e do papel de Porfirio Díaz nesta questão. O país herdado por Díaz tinha um grave defeito de nascença:

Na rude tentativa de aplicar as instituições aprimoradas da civilização anglosaxônica aos descendentes das obscuras raças que habitavam o México antes da descoberta da América por Colombo, os estadistas mexicanos de 1824 colocaram os princípios do governo democrático sob terrível provação.

Nesse contexto, Díaz,

saído de uma infância de pobreza e anonimato, foi alçado ao poder pelas necessidades de um país dividido e desmoralizado; e ele é tão verdadeiramente o produto da fraqueza de seu povo, quanto o México de hoje, pacífico e progressista, resulta em grande medida da força e do bom senso desse líder (Creelman 1911:v).

A entrevista de Creelman com Díaz, contrariamente à biografia posterior, foi escrita em um momento de relativo otimismo em relação ao México, havendo a intenção de traduzi-la e publicá-la em espanhol; assim, esse quadro histórico foi elaborado de modo mais sutil, dando preferência ao panegírico melancólico em detrimento das críticas diretas à raça mexicana. A grandeza de Díaz, portanto, como a do México que ele representava, alcançara seu auge, e o general agora voluntariamente cedia para deixar vir uma nova época, americana:

É algo marcante, vir da balbúrdia da jogatina endinheirada de Wall Street e, na mesma semana, estar no rochedo de Chapultepec, em um cenário de grandiosidade e graça quase irreais, ao lado de alguém conhecido por ter transformado, pela pura compulsão da coragem e força do caráter, uma república em autocracia, e ouvi-lo falar da democracia como a esperança da humanidade (Creelman 1911:232-234).

Nesse veio melancólico, o retrato de Díaz, traçado por Creelman, não difere de entrevista anteriormente publicada, feita por ele com o grande chefe sioux, Touro Sentado:

Lá estava ele - a mais poderosa personalidade de um povo em desaparecimento, cujas fogueiras já ardiam na América quando Salomão ainda não havia construído o templo de Jerusalém - a encarnação da América nativa, com 
faca, machadinha e cachimbo, a encarar um escritor iniciante, de um jornal nova-iorquino, e narrando a história simples de sua raça, que batia em retirada (Creelman 1901:295).

De fato, à medida que se lê em chave racial a entrevista a Creelman, vai ficando mais intrigante, e bem reveladora, a questão do motivo que levou Díaz a escolher aquele jornalista para conceder depoimento tão importante.

Quero de saída dizer que não sabemos com certeza por que Díaz decidiu fazer aquelas tão importantes revelações a Creelman e à Pearson's Magazine. Na ocasião da entrevista, e por muitos anos após, os motivos foram objeto de muita especulação. Bem poucas pessoas do círculo mais próximo a Díaz parecem ter sido informadas de sua decisão a este respeito. O ministro das finanças, José Yves Limantour, por exemplo, lembrava que "os membros do gabinete eu inclusive - e os que eram próximos ao presidente, com exceção de seu secretário particular, não soubemos da entrevista, e ficamos todos igualmente surpresos quando a lemos nos jornais" (Limantour 1965 [1921]:154).

O economista Toribio Ezequiel Obregón, ligado a Díaz, sugeriu que, na sequência da crise de 1907, o governo porfirista desejava acalmar o nervosismo dos investidores americanos quanto à estabilidade mexicana a longo prazo, e que isto explica por que Díaz dirigiu sua entrevista a um público externo, concedendo-a a um jornalista estrangeiro, calculando muito mal os seus efeitos - tanto internos quanto externos (Obregón 1909). As memórias de Limantour sugerem algo diferente, já que o antigo ministro das finanças alega não ter tido conhecimento da entrevista. Na verdade, Limantour perguntou-se a respeito das motivações de Díaz e concluiu que, embora fosse provável que o tradutor e/ou Creelman tivesse(m) exagerado nas respostas, causando danos indevidos, a única explicação para a entrevista seria a diminuição das faculdades mentais de Díaz, causadas pela senilidade (Limantour 1965 [1921]:154-56).

O historiador William Schell, baseando-se em material dos arquivos do Departamento de Estado dos EUA, que não estavam abertos aos contemporâneos de Díaz, verificou que a entrevista foi impingida por altos funcionários americanos: o embaixador David Thompson, o secretário de Estado Elihu Root - que estivera na Cidade do México imediatamente antes da entrevista - e o próprio presidente Roosevelt, com intermediação de seu candidato à sucessão da presidência do México, o governador de Chihuahua, Enrique Creel.

O objetivo de Roosevelt era obter de Díaz uma declaração contrária à reeleição, como parte da tensa negociação com o ditador a respeito da 
política internacional. Roosevelt queria que o México interviesse na - e, provavelmente, que anexasse a - América Central, para estabilizar a região, tornando-a segura para o projeto do Canal do Panamá. Díaz, no entanto, opôs-se sistematicamente à intervenção. Mas ele certamente tinha que negociar com Roosevelt, pois necessitava do apoio deste para debelar a agitação magonista na fronteira. O "esquema" de Roosevelt, no entanto, fracassou, na medida em que a reeleição se deu não obstante a entrevista a Creelman, a instabilidade mexicana não foi evitada, e nem Díaz nem o México serviram como agentes dos EUA na América Central. ${ }^{9}$

Mas ainda assim não sabemos quais foram os cálculos de Díaz nestas questões. Está claro que ele não desaprovou inteiramente o trabalho de Creelman, uma vez que veio subsequentemente a autorizar o jornalista a se tornar seu biógrafo. Na verdade, as perguntas que nos fazemos como historiadores culturais a respeito desse acontecimento são um pouco diferentes daquelas da história política ou diplomática: por que Díaz concedeu uma entrevista-chave e a seguir deu autorização para uma biografia a um jornalista que cobrira todos os empreendimentos imperialistas da época com sistemático racismo chauvinista?

É verdade que Creelman era um jornalista de renome, que entrevistara monarcas europeus, mas seu desprezo pelas raças tropicais era evidente, assim como seu interesse pelos Grandes Homens. Creelman estivera em Cuba, no Haiti, nas Filipinas; cobrira a invasão japonesa na Manchúria; entrevistara Touro Sentado; publicara uma ardorosa defesa do papel da "imprensa marrom" na guerra hispano-americana de 1898, afirmando com aprovação, em relação a Hearst, Pulizer e os demais do grupo, que "o editor moderno raramente se satisfaz, a não ser que sinta que está fazendo a história, além de escrevê-la" (Creelman 1901:358). Por que preferir esse homem, que tinha uma trajetória significativa, bem documentada em publicações, a qualquer dos jornalistas mexicanos acessíveis a Díaz? Por que, com efeito, Díaz posteriormente confiou-lhe a redação de sua defesa e de sua biografia completa?

Há razões políticas que ajudam a explicar a escolha de Díaz: um jornalista americano de tendências mais à esquerda certamente teria escrúpulos em produzir essa espécie de retrato bajulador oferecido por Creelman. Mas há mais do que isso: no início da década de 1900, a ditadura de Díaz tinha sua própria relação de dependência a uma narrativa racista, reproduzida por Creelman. A degradação da nação mexicana e o reconhecimento externo de Díaz, a admiração por ele como tipo humano e por seus feitos históricos davam a ele a estrutura necessária para passar ao público a imagem de um cenário de transição democrática controlada. Assim, as representações degradantes da raça mexicana, como as apresentadas por Creelman, permi- 
tiram à opinião pública americana e mexicana juntar-se ao coro de louvor ao ditador, e afirmar que o país como um todo ainda não merecia coisa melhor; ao mesmo tempo, forneciam uma linguagem melancólica de transição, que servia como dispositivo legitimador do frenesi de fomento ao capitalismo que a ditadura promovia. Nesse contexto, as sutilezas do racismo americano podiam ser exibidas com vantagem como racionalização internacionalmente inteligível, e usadas para aquietar as correntes utópicas da opinião pública, tanto nos EUA quanto no México.

De fato, o cronótopo da dependência proposto por Creelman - uma raça atrasada que poderia ser trazida até o limiar da vida democrática pela pura e simples vontade política - adquirira tal difusão durante a ditadura que ela se tornara senso comum até para a oposição.

Desta forma, apesar de seu declarado desprezo em relação a Creelman, que trabalhara de modo a deixar o apelo de Díaz "desfigurado pela presunçosa e vulgar literatura do jornalismo ianque", Luis Cabrera concordava com a avaliação de Creelman a respeito da conexão entre a grandeza de Díaz e a inferioridade da raça mexicana, ainda que para tirar uma conclusão bem diferente:

Sentindo-se fraco e cansado, o ditador pela primeira vez viu sua obra com a perspicácia que a proximidade da morte traz, e com a clareza de visão que se tem das grandes altitudes. E compreendeu que, porque era a obra de um só homem, e fundada na fraqueza de nossa raça, era quebradiça e inconsistente (Cabrera 1974:28).

A diferença entre Cabrera e Creelman não estava no cronótopo guia, mas sim nas suas implicações políticas, pois enquanto Creelman havia incorrido diretamente no culto ao herói, Cabrera imaginara um Díaz que se encontrava diante da morte, aterrorizado pela condição degradada em que estava deixando seu povo. A entrevista, segundo esta reveladora interpretação, era um pedido de ajuda ao povo mexicano:

E o ditador teve um acesso de terror, como se tivesse escorregado na beirada de um fundo precipício, e deixou escapar aquele pedido por socorro [a entrevista a Creelman], que nada mais era do que um chamado desesperado ao povo mexicano para que salvasse sua obra em ruínas, pois só o povo poderia salvá-la [...] (Cabrera 1974 [1909]:28).

Às vésperas da Revolução Mexicana, a opinião pública do país já se havia inclinado para a opinião americana de um modo sutil e profundo, levando 
figuras políticas a recorrerem, ainda que tacitamente, ao chauvinismo racista dos imperialistas americanos da época, tendo nele um cronótopo manejável com o qual enquadrar o delicado processo político da nação.

\section{John Kenneth Turner e o surgimento e os limites do tempo transnacional}

As relações internacionais, que se expressavam na linguagem do racismo científico ou no idioma popular da fisiognomonia, justificavam a ditadura Díaz e atenuavam a crua realidade, emoldurando-a numa linguagem que falava em transformações. Progresso, para um país racialmente inferior como o México, significava aquisição do aparato necessário para sentar à mesa com as nações civilizadas e progressistas. Era, em outras palavras, um pré-requisito evolutivo para chegar ao verdadeiro progressismo do mundo civilizado.

Mas enquanto as relações internacionais - na política, na comunidade científica e na imprensa - tendiam a reforçar o Estado mexicano, um novo campo de relações transnacionais minava a estrutura dominante do país, no momento mesmo em que o ditador procurava apoio no prestígio da opinião americana. Se travessias de fronteira como as de Lumholtz e de Creelman serviram para qualificar a distopia mexicana - "longe de Deus e perto dos EUA" - e justificar o regime como solução severa porém benigna, a consolidação da fronteira EUA-México deu condições para a formação de uma historicidade mexicana alternativa.

O melhor exemplo desse processo é provavelmente a obra de John Kenneth Turner. Não é coincidência que Turner enquadrasse sua reportagem originalmente publicada com grande sucesso em The American Magazine, na forma de uma série de artigos sobre a escravidão mexicana, posteriormente compilada e ampliada em livro, Barbarous Mexico (1910 [México bárbaro]) como uma resposta ao panegírico de Creelman e, de maneira mais geral, ao modo com que a máquina de Díaz e de seus aliados americanos intermediou a cobertura dos negócios mexicanos nos Estados Unidos.

Se a entrevista a Creelman envolveu uma robusta rede de conexões no topo do sistema político dos EUA e do México, a reportagem de Turner baseava-se em um conjunto igualmente impressionante de conexões entre os dissidentes das duas nações.

Turner decidiu ir para o México por ter conhecido os líderes radicais do partido mexicano de oposição, o Partido Liberal Mexicano, entre eles Ricardo Flores Magón — todos presos, à época, na penitenciária de Los Angeles. 
O encontro com eles não foi obra do acaso. A consolidação da fronteira significava que os grandes capitalistas americanos - os Guggenheims, os Rockefellers, Otis, Hearst, Stillman - agora operavam dos dois lados dela. Também significava que operários mexicanos e soldadores, mercadores e engenheiros americanos trabalhavam nos dois países. Os dissidentes mexicanos nos EUA deparavam-se com o mesmo tipo de assédio enfrentado por membros de associações internacionais de trabalhadores [wobblies] e pelos anarquistas americanos, especialmente nos anos que se seguiram ao assassinato, em 1901, do presidente William McKinley por um jovem anarquista, Leon Gzolgosz. Assédio combinado ao empedernido racismo contra os mexicanos que se desenvolveu no sudoeste americano (Raat 1981; Sandos 1992; Foley 1997; de Leon 1983).

Apesar dessas dificuldades, os Estados Unidos continuaram a ser um ponto estratégico de reunião dos grupos mexicanos de oposição. É possível que a liderança do Partido Liberal Mexicano, fundado em 1902, tenha evitado criar um partido anarquista, mesmo quando se tornou progressivamente mais radical, e que tenha em vez disso mantido a referência "liberal", não só devido às repercussões do liberalismo no México, mas também porque o anarquismo era crime nos EUA e os anarquistas explicitamente proibidos de imigrar para o país. ${ }^{10}$

Segundo seu relato, Turner sentiu-se compelido a ir para o México em função da insistência dos dissidentes a respeito da permanência da escravidão tradicional no país. Sua reportagem representou uma notável realização das possibilidades abertas pelo novo transnacionalismo, e um reenquadramento radical do tempo nacional mexicano. Ela é também um estudo de caso sobre o sucesso limitado (mas não sem consequências) da disseminação de uma nova temporalidade de fronteira, que envolvia a sincronização dos tempos mexicano e americano.

\section{Laços transnacionais dispostos de modo a desestabilizar arranjos internacionais}

A performance de Turner foi "transnacional" em, no mínimo, três aspectos: em primeiro lugar, o projeto se forjou pela solidariedade dentro do movimento sindicalista internacional, que tinha agora sentido, já que os trabalhadores mexicanos e americanos nas minas e nas ferrovias eram empregados pelas mesmas companhias, que operavam nos dois lados da fronteira e enfrentavam nos dois países a oposição da mesma máquina publicitária. ${ }^{11}$ De fato, o esforço de Turner por revelar as condições mexicanas foi uma batalha 
contra Díaz, assim como contra os magnatas da mídia, os políticos e os capitalistas americanos. Em segundo lugar, a reportagem de Turner baseouse principalmente na orientação do socialista mexicano Lázaro Gutiérrez de Lara, que o acompanhou ao longo de toda a viagem. Em terceiro lugar, assim como a entrevista de Creelman, o feito jornalístico de Turner teria sido impossível para um jornalista mexicano: ele só contou com a confiança dos donos de escravos e de capatazes por ser capaz de se fazer passar por investidor americano.

Este duplo status, de forasteiro privilegiado e também de colaborador de membros privilegiados (por serem da oposição), permitiu a Turner desfamiliarizar o quadro em que o México era regularmente apresentado ao público americano. Ele transformou clichês de narrativas de viagem em denúncia de escravidão e servidão mexicanas, denúncia esta sintonizada com as lutas sociais americanas recentes ou em curso nessa época. Em vez de figurar os mexicanos como radicalmente outros, ou como membros renitentes de uma raça "obscura", Turner enfatizou as similaridades entre as condições mexicanas e as condições recentes nos Estados Unidos, especialmente a escravidão e a servidão dos trabalhadores agrícolas nos estados meridionais, como a Flórida, naquela mesma época. ${ }^{12}$ No quadro apresentado por Turner, Díaz não estava elevando o povo do México, mas servindo como peça de um mecanismo destinado a preservar sua inferioridade.

Um dos mais sutis - e radicais - lances de Turner foi o uso de imagens usuais dos escritos de viagem como testemunhos que se encaixavam perfeitamente na nova narrativa, evidenciando assim sua condição distorcida anterior. Desta forma, por exemplo, a imagem de uma índia diante de um cacto - havia então dúzias de cartões-postais com imagens deste tipo recebe a seguinte legenda: "Mãe e criança escravas - e também a planta do sisal", sendo que o cacto, neste caso, era produto do cultivo comercial em torno do qual se instituía a escravidão em Iucatán. ${ }^{13}$

Similarmente, carregadores indígenas levando madeira ou cestos imagem típica na literatura de viagem em todo o século XIX — eram agora enfileirados e mostrados como trabalhadores servilizados.

Turner retrata o México não como lugar exótico, mas como caso extremo dos horrores familiares da tirania, do poder dos trustes e dos monopólios, da servidão de trabalhadores, da rude repressão aos sindicatos e, especialmente, da escravidão - todos estes temas-chave da história da libertação americana. Como exemplo, na comovente história que escreveu sobre a escravização, a deportação e o extermínio dos índios Yaqui, Turner faz uma pausa para esclarecer que "como os maias de Yucatán, eles são índios e, no entanto, não o são. Nos Estados Unidos, não os chamaríamos de índios, pois são traba- 


\section{Figura 9}

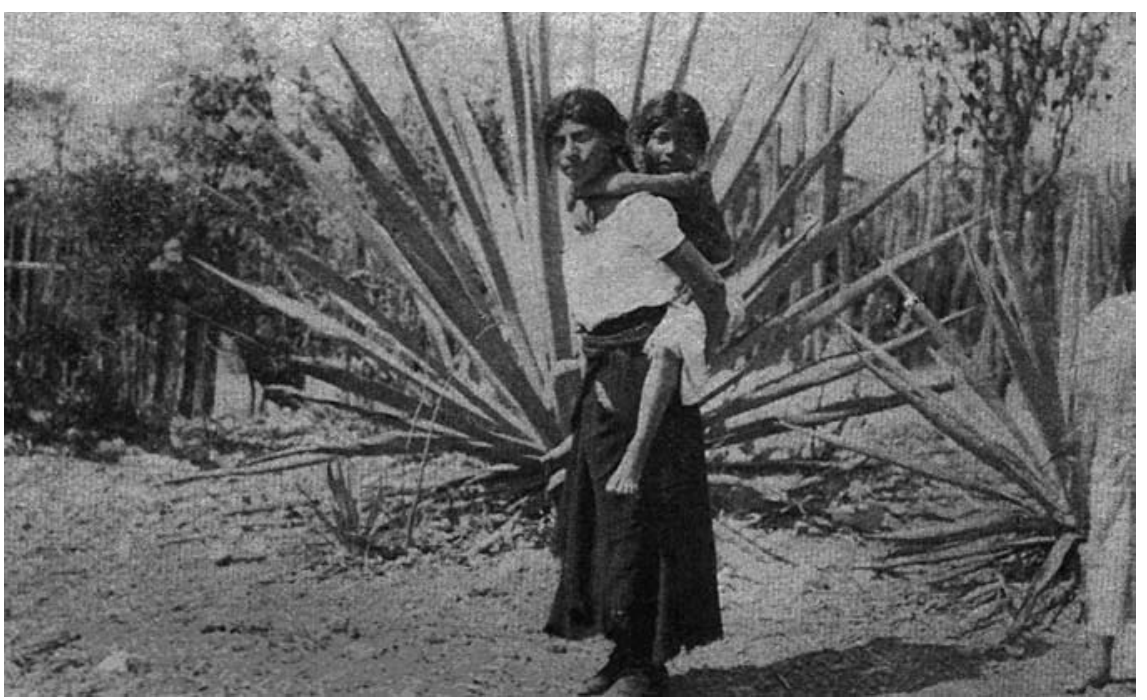

Turner, p. 20

Figura 10

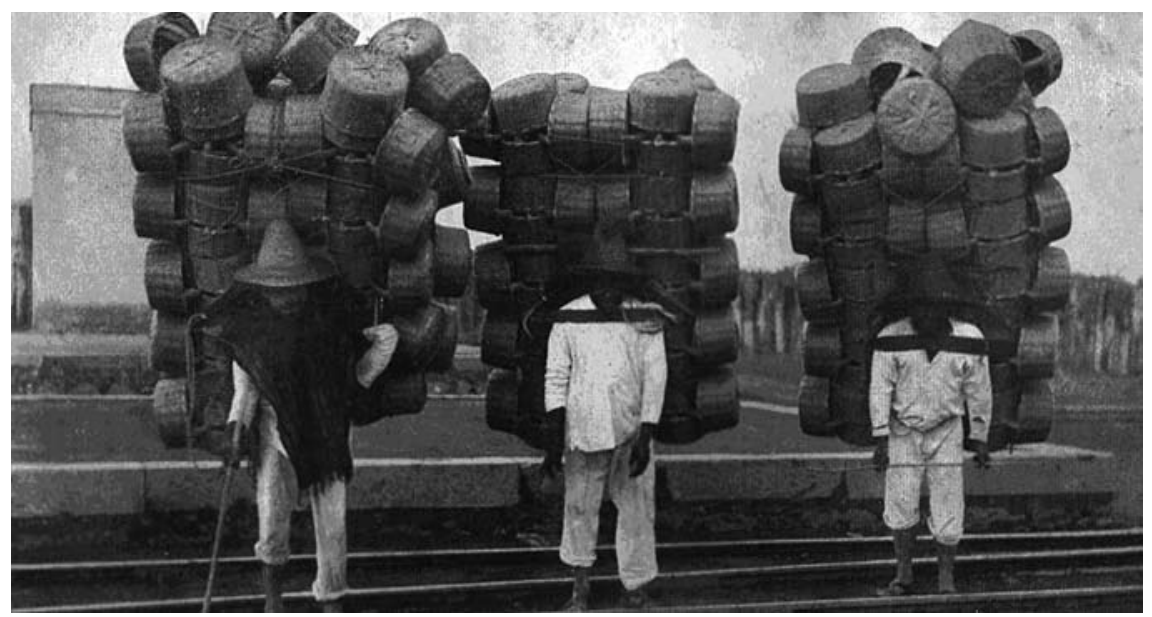

Turner, p. 110

lhadores. Tão longe quanto se possa retroceder em sua história, eles nunca foram selvagens. Eram um povo agrícola" (Turner 1914 [1910]:38).

Quanto às qualidades e às características da raça mexicana, de maneira mais geral, Turner faz a seguinte reflexão: 
os Yaqui são índios, não são brancos, porém quando conversamos com eles em uma língua mutuamente inteligível, ficamos impressionados com a semelhança entre os processos mentais do homem branco e do moreno. Eu cedo tive certeza de que os Yaqui e eu mesmo éramos mais parecidos mentalmente do que na cor da pele. Também estou persuadido de que os laços de família entre os Yaqui não significam para eles menos do que, para os americanos, significam seus próprios laços de família (Turner 1914 [1910]:61).

Através do envolvimento com a separação forçada de maridos e esposas, de pais e filhos, e de discussões detalhadas e bem documentadas a respeito das punições corporais e dos estupros, Turner renarra para o México os temaschave do abolicionismo americano - razão por que seus escritos e posteriormente seu livro, que teve mais de 1 milhão de exemplares vendidos, foram comparados, quanto ao conteúdo e ao impacto, à Cabana do Pai Tomás. ${ }^{14}$

James Creelman falara de Porfirio Díaz como "pai da nação", cujos defeitos pessoais seriam, em todo caso, um reflexo das falhas de seu povo: "e ele é tão verdadeiramente o produto da fraqueza de seu povo, quanto o México de hoje, pacífico e progressista, resulta em grande medida da força e do bom senso desse líder" (Creelman 1911:v). Os rigores da ditadura que ele trouxera seriam o melhor remédio para um povo que, de fato, era incapaz de aceder à democracia, a não ser de modo parcial e muito lentamente:

Pois quando o México atirou-se aos gritos nas formas da democracia anglosaxônica, desafiou sua própria história e suas tradições, ignorou os instintos do sangue que corria em suas veias, esqueceu os arruinados templos e palácios e a extinta civilização de seus povos pré-históricos — voltando-se, em um dia de heróica emoção, para instituições que são possíveis apenas para as nações da mais alta capacidade política -; e aqueles que haviam sofrido juntos em nome da república há muito oprimida recaíram na guerra, inconscientes talvez de que a verdadeira questão era se um princípio ou um método político que fosse verdadeiro ou possível em determinado lugar seria verdadeiro ou possível em todos os lugares, e se raça ou clima ou tempo, ou todos os três juntos, determinariam se uma nação precisa ser temporária ou permanentemente governada de baixo para cima ou de cima para baixo (Creelman 1911:3-4).

Turner virou esse tipo de argumento de cabeça para baixo: "A escravidão e a servidão do México, a pobreza e o analfabetismo, a prostração geral do povo devem-se, em meu humilde juízo, à organização financeira e política que presentemente governa esse país - em uma palavra, ao que designarei o 'sistema' do general Porfírio Díaz" (Turner 1914 [1910]:110). Os interesses 


\section{Figura 11}

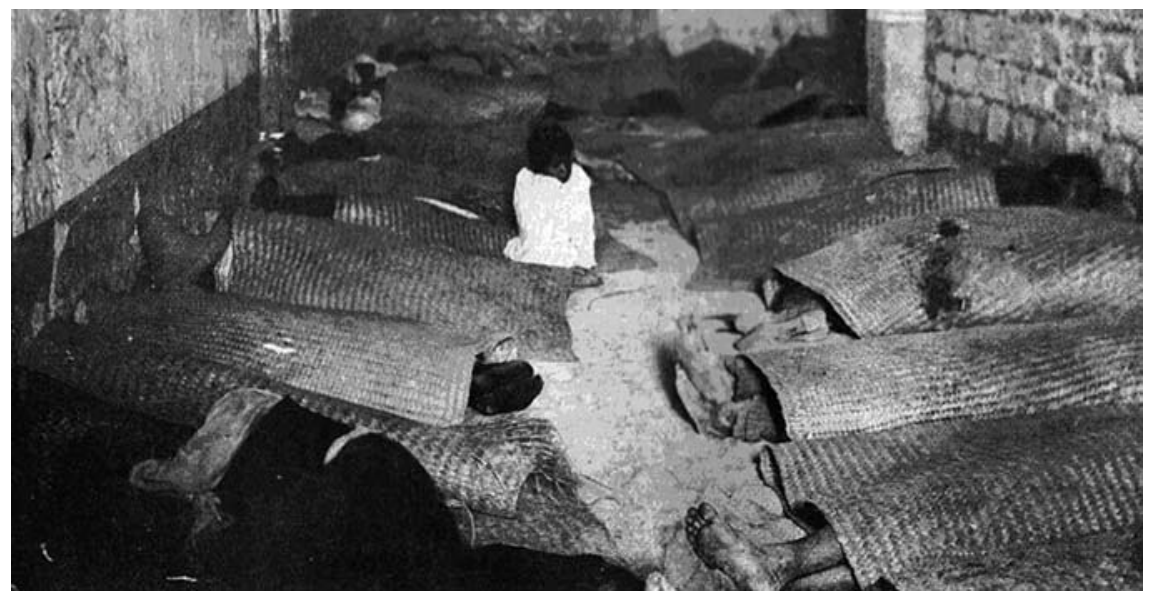

Turner (:116). Difamação mexicana. É interessante que essa estratégia da denúncia social — inteiramente nova no México - tenha permanecido ignorada nos comentários ao trabalho de Turner no país

americanos, ao apoiarem em causa própria a ditadura, davam sustentação externa a um sistema que havia sido erradicado domesticamente. Ao colaborarem com o aparato repressivo de Díaz, "os Estados Unidos se tornaram uma ditadura militar tão sinistra e irresponsável quanto a do próprio Diaz" (Tuner 1914 [1910]:s/p). Díaz, o grupo restrito de latifundiários e donos de escravos, no sul, o bando de jefes politicos e de funcionários corruptos e os magnatas americanos que os apoiavam eram todos uma espécie de reencarnação infernal das castas proprietárias de escravos do sul dos Estados Unidos — infernais porque mais desumanos: "Em minha mente comparei, vez após vez, a condição dos escravos de Yucatan com aquilo que li a respeito dos escravos de nossos estados meridionais antes da Guerra Civil. E sempre o resultado era favorável ao negro" (Turner 1911:35).

Para denunciar o "sistema Díaz", Turner muniu-se de todo um arsenal de técnicas jornalísticas que haviam sido empregadas nos EUA, e assim seu trabalho se coaduna não só com o de Harriett Beecher Stowe e outros abolicionistas, mas também, e muito fortemente, com o dos repórteres de escândalos. Nesse sentido, Turner é o primeiro repórter - e o único, até quanto sei - que chegou a aplicar a técnica desenvolvida por Jacob Riis, em How the other half lives (1889 [literalmente: Como vive a outra metade]), para expor, com fotografias noturnas, tiradas com auxílio de flash, as condições de moradia nas pensões e nos cortiços [mesones] (Troncoso 2005:71-72). 
O efeito combinado da reportagem inspirada nos abolicionistas com as mais poderosas técnicas de documentário de denúncias de escândalos deveuse à colaboração de Turner com os "liberais" mexicanos — representados na obra dele como defensores patrióticos da liberdade, não como anarquistas e foi compreendido de modo muito forte pelo público americano.

No entanto, este não é necessariamente o caso da contrapartida mexicana. Assim, em 1912, após a deposição de Porfirio Díaz, Turner foi honrado com uma entrevista concedida pelo presidente Francisco I. Madero no Castelo Chapultepec, o exato lugar em que Creelman entrevistara Díaz quatro anos antes. Madero contou a Turner que Barbarous Mexico havia sido de grande auxílio para a sua causa, pois permitiu que o povo americano compreendesse que ele, Madero, de fato lutava pela liberdade. ${ }^{15}$ Mas não auxiliara o povo mexicano a levar uma discussão aberta sobre a escravidão e as condições sociais do país.

O livro de Turner só chegaria a uma tradução espanhola em 1955, 47 anos após a publicação dos artigos originais. A primeira edição mexicana, segundo nos lembra Eugenia Meyer, teve prefácio de Daniel Cosío Villegas - na época, o veterano entre os historiadores do México moderno e, ainda hoje, o mais largamente respeitado historiador do porfiriato. Ele não só descartou o valor de Barbarous Mexico como retrato acurado das condições mexicanas, como também, indo adiante, pôs em dúvida a existência da própria pessoa de John Kenneth Turner, especulando que o texto fora redigido por um (anônimo) "liberal" mexicano, e concluindo que era "sem valor, na qualidade de documento científico" e que, em vez disso, poderia ser lido com proveito por seus contemporâneos como um panfleto político particularmente eficaz (Meyer 2005:49-50). Mas a "propaganda" de Turner não teve tanta eficácia dentro do México. Por quê?

Embora os mexicanos tivessem a própria crítica ao trabalho servil no campo e os revolucionários chamassem a atenção para as questões relativas à maioria das condições discutidas por Turner, houve poucas tentativas de sublinhar as similaridades e a sincronicidade entre o México e os Estados Unidos. A recepção fria de Cosío Villegas em relação ao texto de Turner é sintomática — em especial, a reticência em admitir o fato de que Barbarous Mexico poderia ter sido redigido por um americano. Também o livro de John Reed foi deixado por 50 anos sem tradução para o espanhol: publicado em 1954, permaneceu praticamente despercebido até o fim dos anos 1960. Por isso, o escritor e antigo adepto de Pancho Villa, Renato Leduc, escreveu a respeito de sua própria surpresa quando descobriu, em um sebo, que "Johnny, Juanito, o gringo de Chihuahua, sorridente e de nariz arrebitado, não era ninguém menos que o famoso John Reed, cronista heróico da Revolução de Outubro" (Reed 1969 [1914]:17). 
A demora em traduzir, a reticência em acolher, discutir e difundir esses produtos da fronteira, mesmo quando davam apoio às ideias da revolução mexicana, são testemunhos do fato de que as tensões entre os dois cronótopos que examinamos permaneceram. Após a revolução, o tempo nacional ainda era expresso mais em referência ao cronótopo de Creelman do que ao de Turner. O tempo nacional teve modos de enquadramento que ainda hesitavam em abarcar a contemporaneidade do México e dos Estados Unidos.

Recebido em 11 de agosto de 2008

Aprovado em 18 de agosto de 2008

Tradução de Amir Geiger

Claudio Lomnitz é professor de antropologia na Columbia University. E-mail: $<$ cl2510@columbia.edu>

\section{Notas}

* Uma versão inicial deste artigo foi apresentada no Davis Seminar, em Princeton. Sou grato aos seus membros pelos comentários. Mauricio Tenorio, Carlos Bravo, Friedrich Katz e Alan Wells indicaram-me material útil. Tenho uma dívida de gratidão para com Sharrona Pearl pelas informações que deu sobre fisiognomonia. Valem aqui os esclarecimentos de praxe.

${ }^{1}$ Esse quadro fomentou uma linguagem — credível, porém sempre desafiada — de perpétua transição, que se tornou objeto de crítica e de elaboração século XX adentro. O exemplo paradigmático é Samuel Ramos, que introduziu um tipo de freudismo na filosofia mexicana em sua obra de 1930 sobre o caráter nacional; ele afirmava que os mexicanos sofriam de complexo coletivo de inferioridade. Isto implicava que tal "complexo", que tinha como sujeito típico-ideal o pelado da classe baixa urbana, era principalmente uma mentalidade, portanto, curável. Abria-se, com o estado revolucionário, um horizonte terapêutico para curar os mexicanos de sua "distância de Deus" (Ramos 1938 [1931]). Para uma crítica brilhante das teorias mexicanas do eterno devir, ver Bartra 1987.

${ }^{2}$ Ver a impressionante compilação de Matías Romero 1898. 
${ }^{3}$ Ver Mauricio Tenorio 1996 \& Justo Sierra 1900.

${ }^{4}$ Para uma visão geral, ver John Mason Hart (ed.) 1998.

${ }^{5}$ Ver, por exemplo, sobre a cidade de San Antonio (Texas), Daniel Arreola 1987.

${ }^{6}$ Os principais trabalhos sobre a entrevista: Blanquel 1978; Schell Jr. 2001.

${ }^{7}$ Sharrona Pearl, comunicação escrita, 4/02/2007.

${ }^{8}$ Para um relato detalhado da triste história de Máximo e Bartola, ver Comas 1968 e Rothfels 1996. Bartola e Máximo foram exibidos pela primeira vez no Circo Barnum, e em tours ininterruptos, especialmente na Europa, até pelo menos 1901. Morreram em data desconhecida. Embora sua condição de "Astecas" tenha sido rapidamente contestada por alguns cientistas, a fama das "Crianças Astecas" e sua influência na opinião pública foi ampla, profunda e duradoura, e eles foram vistos e debatidos não só pelo público mais amplo, mas também pelos monarcas da GrãBretanha e da Prússia, assim como por cientistas europeus e americanos de destaque, já em 1900. O retrato desenhado de Máximo, no livro de Redfield, é cópia de um desenho publicado no American Journal of Medical Sciences, v. 25:290, 1851.

${ }^{9}$ Schell 2001, capítulo 6.

${ }^{10}$ Turner descreve o uso pelas autoridades americanas da lei de imigração inclusive a cláusula antianarquista - como estratagema para colaborar de modo direto e próximo com a máquina repressiva de Díaz (Turner 1914 [1910]:272-279).

${ }_{11}$ A greve na mina de cobre de Cananea (1906) deu oportunidade a uma aproximação entre os governos de Díaz e de Roosevelt; o México aceitou a política de Roosevelt na América Central em troca do apoio americano no policiamento dos magonistas nos EUA, e da troca de informações quanto às atividades na fronteira (Schell 2001, capítulo 6).

${ }^{12}$ Quando Turner escreveu seus artigos, a campanha contra o trabalho rural servil no sul ainda estava viva nos debates públicos americanos. Ver Pete Daniel 1972 .

${ }^{13}$ Para a história da fotografia no México, ver Debroise 2001; Treviño 2005; Krinsky (ed.) 2005.

${ }^{14}$ Para uma discussão, ver Eugenia Meyer 2005:13.

${ }^{15}$ J. K. Turner, correspondência, 1912, citado em E. Meyer, 2005:55. 


\section{Referências bibliográficas}

ALONSO, Ana. 1997. Thread of blood: colonialism, revolution, and gender on Mexico's northern frontier. Tucson: University of Arizona Press.

ARREOLA, Daniel. 1987. "The mexican american cultural capital". Geographical Review, 77(1):17-34.

BAKHTIN, Michael. 1981. "Forms of time and the chronotope in the novel". In: The dialogic imagination: four essays by M.M.Bakhtin. Translated by Caryl Emerson and Michael Holquist. Austin: University of Texas Press. pp. 84-258.

BARTRA, Roger. 1987. La jaula de la melancholia. Mexico City: Grijalbo.

BLANQUEL, Eduardo. 1978. "Setenta años de la entrevista Díaz-Creelman". Vuelta, 2(17):28-33.

CABRERA, Luis. 1974 [1909]. "El grito de Chapultepec". In: Obras Completas, v. 2 Mexico City: Editorial Oasis. pp. 18-28.

CARDOSO, Fernando Henrique \& FALETTO, Enzo. 1979. Dependency and development in Latin America. Translated by Marjory Mattingly Urquidi. Berkeley: University of California Press.

COMAS, Juan. 1968. Dos microcéfalos "aztecas": leyenda, historia y antropología. México: UNAM.

CREELMAN, James. 1901. The wanderings and adventures of a special correspondent. Boston: Lothrop Publishing Company. . 1908. "President Diaz, hero of the Americas". Pearson's Magazine, XIXX(3):231-232. . 1911. Diaz, master of Mexico. New York: D. Appleton and Company.

DANIEL, Pete. 1972. The shadow of slavery: peonage in the South, 1901-
1964. Urbana: University of Illinois Press.

DEBROISE, Olivier. 2001. Mexican suite: a history of photography in Mexico. Austin: University of Texas Press.

FOLEY, Neil. 1997. White scourge: mexicans, blacks and whites in Texas cotton culture. Berkeley: University of California Press.

GRAY, Richard. 2004. About face: german physiognomic thought from Lavatier to Auschwitz. Detroit: Wayne State University.

HART, John Mason. 1987. Revolutionary Mexico: the coming and process of the mexican revolution. Berkeley: University of California Press. pp. 129-162. . (ed.). 1998. Border crossings: mexican and mexican-american workers. Wilmington, Del.: SR Books. . 2002. Empire and revolution: the americans in Mexico since the Civil War. Berkeley: University of California Press.

KRINSKY, Emma Cecilia García (ed.). 2005. Imaginarios y fotografía en México: 1839-1970. Barcelona: Lunweg.

LEON, Arnoldo de. 1983. They called them greasers: anglo attitudes toward mexicans in Texas, 1821-1900. Austin: University of Texas Press.

LIMANTOUR, José Yves. 1965 [1921]. Apuntes sobre mi vida pública. México: Editorial Porrúa.

LUMHOLTZ, Carl. 1987 [1902]. Unknown Mexico: explorations in the Sierra Madre and other regions, 1890-1898. vol.1. New York: Dover Publications.

MEYER, Eugenia. 2005. John Kenneth Turner, periodista de México. Mexico City: Ediciones Era. 
NUGENT, Daniel (ed.). 1998. Rural revolt in Mexico: US intervention and the domain of subaltern politics. Durham: Duke University Press.

OBREGÓN, Toribio E. 1909. "El epílogo de la conferencia Creelman sera la entrevista Díaz-Taft". El Antirreeleccionista, september 23.

PEARL, Sharrona. 2005. As plain as the nose on your face: physiognomy in $19^{\text {th }}$ century England. Ph.D. Dissertation, History of Science, Harvard University.

RAAT, Dirk. 1981. Revoltosos: Mexico's rebels in the United States, 19031920. College Station, Texas: A \& M Press.

RAMOS, Samuel. 1938 [1931]. Perfil del hombre y la cultura en México. Mexico City: P. Robredo.

REDFIELD, James. 1852. Comparative physiognomy or resemblances between men and animals. New York: Redfield, Clinton Hall.

REED, John. 1969 [1914]. Insurgent Mexico. New York: International Publishers.

ROMERO, Matías. 1892. Artículos sobre México publicados en los Estados Unidos de América. México: Oficina Impresora de Estampillas. - 1898. Mexico and the United States: a study of the subjects affecting their political, commercial, and social relations, made with a view to their promotion. New York: G.P.Putnam's sons.

ROTHFELS, Nigel. 1996. "Aztecs, aborigines, and ape-people: science and freaks in Germany, 1850-1900". In: R. Thomson (ed.), Freakery: cultural spectacles of the extraordinary body. New York: NYU Press. pp.158-172.

SANDOS, James. 1992. Rebellion in the borderlands: anarchism and the plan de San Diego, 1904-1923. Norman: Univ. of Oklahoma Press.
SCHELL, William. 2001. Integral outsiders: the american colony in Mexico City, 1876-1911. Wilmington, Del.: SR Books.

SIERRA, Justo. 1900. Mexico, its social evolution. 3 vols. Barcelona: Ballescá editors.

TENORIO, Mauricio. 1996 Mexico at the worlds fairs. Berkeley: University of California Press.

TREVIÑO, Estela. 2005. 160 años de fotografía en México. Mexico: CONACULTA/CENART/Océano.

TRONCOSO, Alberto del Castillo. 2005. "La historia de la fotografía en México". In: Rosa Casanova et alli (eds.), Imaginarios y fotografía en México. Barcelona: Lunwerg. pp. 71-72.

TURNER, John Kenneth. 1914 [1910]. Barbarous Mexico. Chicago: Charles H. Kerr \& Co. . 1911. Barbarous Mexico. Chicago: Charles H. Kerr \& Co. 3a. ed.

VANDERWOOD, Paul. 1998. The power of god against the guns of government: religious upheaval in Mexico at the turn of the nineteenth century. Stanford: Stanford University Press.

WELLS, Samuel R. 1894 [1869]. How to read character: a new illustrated hand-book of phrenology and physiognomy for students and examiners. New York: Fowler and Wells Co., Publishers.

YOUNG, Elliott. 2004. Catarino Garza's revolution on the Texas-Mexico border. Durham: Duke University Press. 
Resumo

Este artigo desenvolve uma nova abordagem sobre a antropologia e a história de fronteiras nacionais. Ele propõe uma tipologia e uma caracterização fenomenológica de duas formas de se atravessar a fronteira que surgiram paralelamente a uma nova relação de dependência econômica e política entre o México e os Estados Unidos da América no final do século XIX. Tais novas modalidades de se atravessar a fronteira envolvem o desenvolvimento de novos "cronótopos", ou seja, novas e concorrentes matrizes espaços-temporais que foram utilizadas para enquadrar a relação entre o México e os EUA. Este artigo analisa a qualidade, a natureza e o preço destas formas alternativas de historicidade por intermédio de uma análise detalhada de dois textos jornalísticos cruciais: a entrevista do General Porfírio Diaz por James Creelman (1908) e a reportagem de Kenneth Turner sobre a escravidão mexicana (1910).

Palavras-chave Estudos de fronteira, Cronótopos, Dependência, Relações entre México e EUA, Raça

\section{Abstract}

This paper develops a novel approach to anthropology and history of international borders. It proposes a typology and a phenomenological characterization of two kinds of border crossings that emerged alongside the new relationship of economic and political dependency that developed between México and the United States in the last quarter of the 19th century. The new border crossings involved the development of new 'chronotopes', in other words new and competing spatial-temporal matrices, used to frame the relationship between México and the United States. This paper analyzes the quality, nature and stakes of these alternative forms of historicity by way of a close case study of two pivotal journalistic texts: James Creelman's (1908) interview of General Porfírio Diaz, and John Kenneth Turner's (1910) reportage and exposé of Mexican slavery.

Key words Border studies, Chronotopes, Dependency, México-US Relations, Race 